\author{
IN THIS ISSUE \\ DUNCAN HILCHEY
}

\title{
Gleanings from the field
}

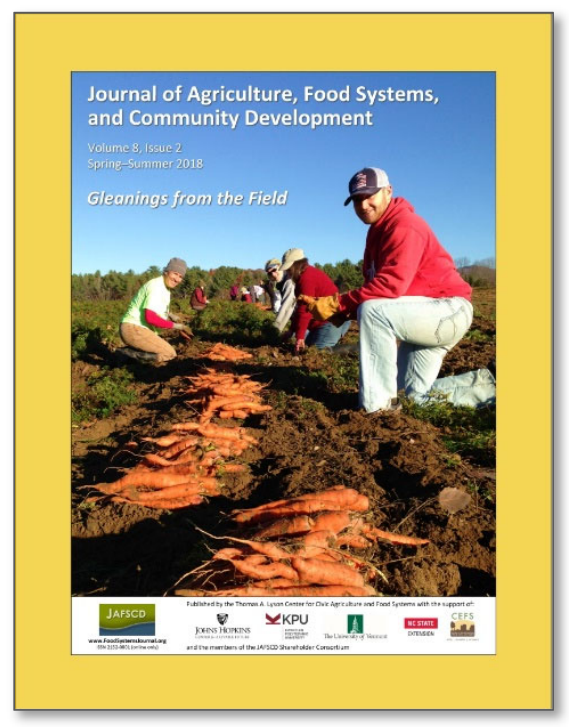

Published online July 5, 2018

Citation: Hilchey, D. (2018). G leanings from the field [Editorial]. Journal of A griculture, F ood Systems, and Community D evelopment, 8(2), 1-3. http:// dx.doi.org/ 10.5304/ jafscd.2018.082.017

Copyright @ 2018 by the Author. Published by the Lyson Center for Civic Agriculture and Food Systems. Open access under CC BY license.

$\mathrm{F}_{\mathrm{b}}^{\mathrm{o}}$ ood waste and food rescue have been hot topics in recent years (although gleaning dates back to at least biblical times in the ancient traditions of tzedakah and pe'ah). O ur cover photo for this issue, courtesy of Salvation Farms, shows a group of volunteers joining Salvation Farms and two other Vermont Gleaning Collective organizations gleaning a crop of carrots too large and misshapen for market. I first learned of the great work Salvation Farms is doing a couple of years ago from the Food Feed blog (https:/ / learn.uvm.edu/ foodsystemsblog/) of the University of Vermont (a founding partner of JAFSCD). Salvation Farms had just published a report assessing on-farm food loss in Vermont, and I thought its methodology should be peerreviewed and in the applied research literature. I contacted report authors Elana D ean and Salvation Farms director Theresa Snow and suggested they find a scholar who could work with them on a manuscript. They found Roni Neff, a food-waste expert at the Johns Hopkins Center for a Livable Future (coincidentally also a founding partner of JAFSCD). Their collaboration has yielded a seminal work on estimating on-farm food loss. I share this story as a model of food system researchers and professionals collaborating to produce applied research that benefits all parties concerned - and the greater community. We are likely to do a special issue on food waste in the near future, and we hope to see more researcher-professional collaborations like this one.

In this open call issue, we give you our spring and summer gleanings from the field and elsewhere in the

On our cover: A group of volunteers joins Salvation Farms and two other Vermont G leaning Collective organizations at Gildrien Farm just south of Middlebury, Vermont, on a sunny, late fall morning to glean a crop of carrots too large and misshapen for market. In a few hours, more than 30 volunteers from the community harvested over 11,000 pounds $(4,990 \mathrm{~kg})$ of carrots. The majority of the harvest was received by Salvation Farms' Vermont Commodity Program, where individuals enrolled in a work-readiness training program cleaned and packaged the carrots for distribution to charitable food sites across V ermont. See Salvageable F ood L osses from V ermont Farms in this issue (https:/ / doi.orq/ 10.5304/ iafscd.2018.082.006).

Photo credit: Salvation Farms; used with permission. 
food system. We start out this issue with John Ikend's Economic Pamphleteer column. In A Farm Bill for the A griculture W e W ant, John makes a compelling case for replacing commodity-based insurance programs with a comprehensive, subsidized "whole farm net revenue" insurance program.

Next, we offer a viewpoint by Laura Schreiner, Charles Levkoe, and Theresa Schumilas, entitled Categorizing Practical Training Programs for N ew Farmers: A N orth A merican Scan, in which they take the first crack at surveying and typologizing a broad range of new and beginning farmer training programs in the U.S. and Canada, and call for an ongoing census and impact analysis of these program in the future.

In our first installment of Voices from the Grassroots, Six C ritical Solutions to Fix Peoria's Community E mergency Food A ssistanœ System, Kim Keenan of The gitm (Gifts in the Moment) Foundation provides a roadmap for local agencies in an American Heartland city to coordinate their activities more in reducing food insecurity.

Next is a paper from the EFSNE project, Baselines, Trajectories, and Scenarios: E x ploring A gricultural Production in the N ortheast U.S. Timothy Griffin, Christian Peters, David Fleisher, Michael Conard, Zach Conrad, Nicole Tichenor, Ashley McCarthy, Emily Piltch, Jonathan Resop, and Houman Saberi make very detailed estimates of regional food production potential in the Northeast. See volume 7, issue 4 (https:/ / www.foodsystemsjournal.org/ index.php/ fsj/ issue/ view/ 29) for other papers in this series.

O ur first open call paper is also our title paper: Salvageable $\mathrm{F}$ ood L osses from $\mathrm{V}$ ermont $\mathrm{F}$ arms. In it, Roni Neff, Elana Dean, Marie Spiker, and Theresa Snow provide an estimate and new methodology for calculating on-farm food loss on farms in Vermont and consider how reducing it could put more fresh food on the plates of those who need it.

Next, Amy Guptill, David Larsen, Rick Welsh, and Erin Kelly explore the relative importance of privileged customers in the local food movement in D o A ffluent U rban C onsumers D rive D irect F ood Sales in the N ortheast U nited States? A Threepart A nalysis.

In The SN A P C hallenge: C ommunicating F ood Security C apabilities through A nti-H unger A dvocacy, Kathleen Hunt documents the difficulty of surviving on less than US\$132 per month for food - the maximum amount allowed for individual SNAP recipients.

U rban Farmers M ark ets as a Strategy to Increase A cess to and C onsumption of F resh V egetables among SN A P and non-SN A P Participants: Results from an E valuation, by Rebecca Woodruff, Kimberly Arriola, Kia PowellThreets, Rashid N uni, Carol H unter, and Michelle Kegler, explores whether farmers markets have their intended impact on SNAP recipients.

Charles Levkoe, Colleen Hammelman, Luke Craven, Gavin Dandy, Jeff Farbman, James Harrison, and Phil Mount then present the collective findings of a diverse group of food hub experts In Building Sustainable Communities T hrough F ood H ubs: Practitioner and A cademic Perspectives.

In Three year $\mathrm{C}$ ase Study of $\mathrm{N}$ ational $\mathrm{O}$ rganizations Participating in a $\mathrm{N}$ utrition $\mathrm{C}$ ohort: $\mathrm{A}$ U nique F under-initiated L earning C ollaborative, Sarah Amin, Megan Lehnerd, Sean Cash, Christina Economos, and Jennifer Sacheck find that trust building among participants is job \#1 when creating learning collaboratives (or communities of practice).

In our final open call paper, Soil C ontaminant C onœentrations at U rban A gricultural Sites in N ew 0 rleans, L ouisiana: A C omparison of T wo A nalytical M ethods, Kyle Moller, James Hartwell, Bridget Simon-Friedt, Mark Wilson, and Jeffrey Wickliffe take us one step closer to identifying the most cost-effective methods of identifying contaminants in urban soils.

Finally, we offer five book reviews. First, Teresa Mares reviews A F oodie's G uide to Capitalism: Understanding the Political E conomy of W hat W e E at by Eric Holt-Giménez (Monthly Review Press).

Amber H eckelman reviews Selling L ocal: W hy L ocal F ood M ovements M atter, by Jennifer Meta Robinson and James Robert Farmer (Indiana University Press).

Dancy Mullen reviews A Precautionary Tale: $\mathrm{H}$ ow 0 ne Small Town Banned Pesticides, Preserved Its F ood $\mathrm{H}$ eritage, and Inspired a M ovement, by Philip Akerman-Leist (Chelsea Green Publishing).

Salma Loudiyi reviews The Politics of F ood Sovereignty: C oncept, Practice and Social M ovements, edited by Annie 
Shattuck, Christina Schiavoni, and Zoe VanGelder (Routledge).

And finally, Keith Williams reviews F ood L eadership: L eadership and L earning for G lobal F ood Systems Transformation, edited by Catherine Etmanski (Sense Publishers).

I want to take this opportunity to encourage nonprofit, agency staffers, food policy council members, activists, consultants and others working in food systems to contribute 1,000-word Voices from the Grassroots commentaries at any time. $\mathrm{V}$ oices is a new professional-development opportunity for those folks working on the front lines of the good food movement. It's also a great way to share your experiences and best practices with colleagues around the world, and to share your needs with policy-makers and may present opportunities to collaborate with researchers. Find details at https:/ / www.foodsystemsjournal.org/ index.php/ fsj/ grassroots.

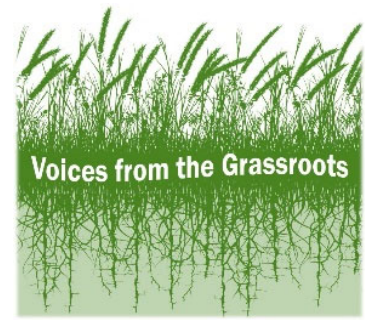

With appreciation,

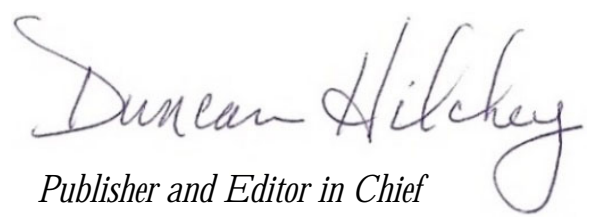

